\title{
Role of bone marrow aspiration and biopsy in elaborating the diagnosis of pancytopenia
}

\author{
Chandan R.H ${ }^{1}$, Giriyan S.S \\ ${ }^{1}$ Dr. Rajesh H Chandan, Associate Professor, ${ }^{2}$ Dr. Sujata S Giriyan, Professor and Head of the Department, Department \\ of Pathology, Karnataka Institute of Medical Sciences, Hubballi, Karnataka, India.
}

Corresponding Author: Dr. Rajesh H Chandan, Associate Professor, Department of Pathology, KIMS, Hubballi Karnataka, India. Email: drchandanrajesh@gmail.com

\begin{abstract}
Background and Aims: Pancytopenia may be a manifestation of a wide variety of disorders which primarily or secondarily affects the bone marrow. Bone marrow failure syndromes and malignancies are serious and life threatening causes, but certain non-malignant conditions such as infection, and nutritional anemia are equally important. The severity of pancytopenia and the underlying pathology determine the implementation of correct management and prognosis. Materials and Methods: This was a prospective study conducted for a period of two years on 134 patients of pancytopenia. Detailed history, thorough clinical examination, complete hemogram, peripheral smear examination, reticulocyte count evaluation and bone marrow aspiration was performed in all cases. In addition, trephine biopsy was done in the same setting wherever indicated. Results: The age ranged from 15 to 75 years with a mean age of 30.9 years. The most common cause of pancytopenia was Megaloblastic anemia (37\%) followed by Nutritional anemia (31\%), aplastic anemia (9\%) and Leukemia (1.75\%). Majority (79\%) of the patients had hyper cellular bone marrow followed by hypocellular (13\%) and normal cellular marrow (8\%). Conclusion: Elaborate hematological investigations and bone marrow examination, both, in correlation with clinical findings are vital for the diagnosis of pancytopenia. Bone marrow Aspiration and Trephine biopsy, complement each other in diagnosis of challenging cases
\end{abstract}

Key words: Bone marrow examination, Hematological malignancy, Hypoplastic anemia, Megaloblastic anemia, Pancytopenia

\section{Introduction}

The spectrum of disorders affecting the bone marrow may manifest with pancytopenia which is defined as reduction in all the three formed elements of blood below the normal reference range. The presenting symptoms are often due to either anemia or thrombocytopenia and leukopenia which develops subsequently. Various disorders manifest with features of pancytopenia [1]. Bone marrow aspiration establishes the diagnosis and bone marrow biopsy is mandatory only in cases of unsuccessful tap or wherever indicated $[1,2]$. This study aims to identify the etiological factors of pancytopenia in patients aged more than 15years and to ascertain the bone marrow morphology in those cases. In addition, this study emphasizes upon the importance of bone marrow aspiration and biopsy in Pancytopenia in diagnosing the underlying cause for the same.

Manuscript received: $20^{\text {th }}$ March 2018

Reviewed: $30^{\text {th }}$ March 2018

Author Corrected: $6^{\text {th }}$ April 2018

Accepted for Publication: $11^{\text {th }}$ April 2018

\section{Materials and Methods}

Type, place and duration of study: This was a prospective observational study, conducted in the Department of Pathology, Karnataka Institute of Medical Sciences, for a period of two years from November 2012 to May 2014.

Sample Size: 134 cases based on inclusion and exclusion criteria

Sample Selection: All the in-patients more than 15years of age diagnosed as pancytopenia during the two years duration were included for the study.

Critically ill patients, patients with severe thrombocytopenia $(<10,000 /$ cumm $)$, chemotherapy induced pancytopenia patients and non-cooperative patients were excluded from the study. Clinical history and examination of all the caseswas noted as per the proforma. With proper consent from the patients, bone 
marrow aspiration was performed on all cases. Bone marrow biopsy compliments the aspiration study and was done in cases where additionally indicated or unsuccessful tap and slides were studied.

\section{Original Research Article}

Statistical Methods: The data obtained was tabulated analysed using frequencies, percentages, graphical representations and tests for significance wherever applicable.

\section{Results}

One hundred and thirty-fourpatients with a pancytopenia were studied during the two years. Most of the patients were in the age group of 21-30years (28\%) and the least occurrence was seen in the age group of 15-20years ( $8 \%$ ) (Table 1). The male to female ratio was $1.6: 1$.

Table-1: Age and sex distribution of patients with pancytopenia in the present study.

\begin{tabular}{|c|c|c|c|c|}
\hline Age group (years) & Male & Female & Total number of cases & Percentage (\%) \\
\hline $15-20$ & 7 & 15 & 22 & 8 \\
\hline $21-30$ & 23 & 17 & 40 & 28 \\
\hline $31-40$ & 17 & 11 & 28 & 23 \\
\hline $41-50$ & 19 & 4 & 9 & 10 \\
\hline $51-60$ & 8 & 1 & 12 & 11 \\
\hline $61-70$ & 9 & 3 & $\mathbf{1 3 4}$ & $\mathbf{1 0 0}$ \\
\hline Total & $\mathbf{8 3}$ & $\mathbf{5 1}$ & \\
\hline
\end{tabular}

Easy fatigability $(25 \%)$ and fever $(24 \%)$ were the most common symptoms in pancytopenic patients. Hemoglobin percentage varied from $1-12 \mathrm{gm} \%$. Majority of patients $(35 \%)$ had hemoglobin in the range of $3.1-5 \mathrm{gm} \%$. $12 \%$ of patients had hemoglobin in the value of 1-3 gm\%.The total leukocyte count was in the range of 500-4000 cells/cumm. The platelet count ranged from 4000-1,50,000 cells/cumm. The range of mean corpuscular volume was 51-138 fl.

Type and percentage of cellularity of bone marrow in the current study is depicted in table2.

Table-2: Cellularity of Bone marrow

\begin{tabular}{|c|c|}
\hline Cellularity & Percentage \\
\hline Hypercellular & $62 \%$ \\
\hline Normocellular & $26 \%$ \\
\hline Hypocellular & $6 \%$ \\
\hline Inconclusive & $6 \%$ \\
\hline
\end{tabular}

Pancytopenia associated with hypocellular marrow- In the present study, 8 out of 134 patients had hypocellular bone marrow and they were diagnosed as Aplastic anemia with a peak incidence $(37 \%)$ in the age group of (31-40 yrs). Aplastic anemia was more common in females (67\%). Hb\% varied from 2.5-10 gm\%. TLC ranged from 600-3000 cells/cumm. Platelet count ranged from 7000-1,00,000 cells/cumm. Majority of the patients had dimorphicblood picture with microcytic hypochromic and macrocytic erythrocytes. Bone marrow was hypocellular with an increase in marrow fat. Lymphocytes and plasma cells were prominent.

Table 3 depicts the incidence and conditions associated with hypercellular and normocellular marrow.

Table-3: Pancytopenia with hypercellular and normocellular bone marrow in the present study.

\begin{tabular}{|c|c|c|c|c|c|c|}
\hline \multirow{2}{*}{ Etiology } & \multicolumn{2}{|c|}{ Hypercellular } & \multicolumn{2}{c|}{ Normocellular } & \multicolumn{2}{c|}{ Total number of cases } \\
\cline { 2 - 7 } & No. & $\mathbf{( \% )}$ & No. & $\mathbf{( \% )}$ & No. & $(\%)$ \\
\hline Megaloblastic anemia & 43 & 86 & 7 & 14 & 50 & 37 \\
\hline Nutritional anemia & 22 & 54 & 19 & 46 & 41 & 31 \\
\hline Hypersplenism & 15 & 68 & 7 & 32 & 22 & 16 \\
\hline Acute leukemia & 2 & 100 & & & 2 & 1.75 \\
\hline Multiple myeloma & & & 1 & 100 & 1 & 0.75 \\
\hline MDS & & & 1 & 100 & 1 & 0.75 \\
\hline NEH with Cryptococci & & & 1 & 100 & 1 & 0.75 \\
\hline
\end{tabular}




\section{Original Research Article}

Hematological parameters were tabulated for cases with hypercellular and normocellular marrow (table4).

Table-4: Haematological Parameters for Normocellular and Hypercellular marrow

\begin{tabular}{|c|c|c|c|c|c|c|c|c|}
\hline \multicolumn{2}{|c|}{$\begin{array}{c}\text { Parameters/ Bone marrow } \\
\text { cellularity }\end{array}$} & MBA & MNA & Hypersplenism & $\mathbf{A L}$ & MM & $\begin{array}{c}\text { MD } \\
\text { S }\end{array}$ & $\begin{array}{l}\text { Cryptoco } \\
\text { ccal }\end{array}$ \\
\hline \multirow{4}{*}{$\begin{array}{l}\text { Haemoglobin } \\
\mathrm{g} / \mathrm{dl}\end{array}$} & $1-3$ & 12 & 2 & 0 & 0 & 0 & 0 & 0 \\
\hline & $3.1-5$ & 20 & 9 & 10 & 1 & 1 & 0 & 0 \\
\hline & $5.1-7$ & 12 & 16 & 8 & 0 & 0 & 1 & 1 \\
\hline & $7.1-10$ & 6 & 14 & 4 & 1 & 0 & 0 & 0 \\
\hline \multirow{4}{*}{$\begin{array}{l}\text { Leucocyte } \\
\text { Count } \\
\text { Cell/cumm }\end{array}$} & 500-1000 & 1 & 3 & 3 & 1 & 0 & 0 & 0 \\
\hline & $1001-2000$ & 21 & 12 & 6 & 1 & 0 & 0 & 0 \\
\hline & $2001-3000$ & 18 & 11 & 8 & 0 & 0 & 0 & 0 \\
\hline & $3001-4000$ & 10 & 15 & 5 & 0 & 1 & 1 & 1 \\
\hline \multirow{5}{*}{$\begin{array}{l}\text { Platelet count } \\
\text { Cells/cumm }\end{array}$} & $4000-25,000$ & 10 & 9 & 2 & 1 & 0 & 0 & 0 \\
\hline & $25,001-50,000$ & 20 & 13 & 9 & 0 & 0 & 1 & 0 \\
\hline & $50,001-75,000$ & 9 & 11 & 4 & 0 & 0 & 0 & 0 \\
\hline & $75,001-1 \mathrm{~L}$ & 6 & 5 & 2 & 1 & 1 & 0 & 1 \\
\hline & $1 \mathrm{~L}-1.5 \mathrm{~L}$ & 5 & 3 & 5 & 0 & 0 & 0 & 0 \\
\hline
\end{tabular}

Megaloblastic Anemia (MBA), Mixed Nutritional Anemia MNA, AL - Acute Leukemia, Multiple Myeloma MM), Myelodystrophic syndrome (MDS)

\section{Discussion}

Pancytopenia is a serious hematological entity, which makes the patient prone to anemic manifestations, infections and bleeding tendency. Underlying it are many diseases, which are diagnosed by means of predominantly bone marrow

Table-5: Comparison of causes of pancytopenia in different studies

\begin{tabular}{|c|c|c|c|c|c|c|}
\hline $\begin{array}{l}\text { S. } \\
\text { No. }\end{array}$ & Study & Country & Year & $\begin{array}{l}\text { Noof } \\
\text { cases }\end{array}$ & $\begin{array}{c}\text { Commonest cause } \\
(\%)\end{array}$ & $\begin{array}{c}2^{\text {nd }} \text { commonest } \\
\text { cause }(\%)\end{array}$ \\
\hline 1. & Jha et al[5] & Nepal & 2008 & 148 & $\begin{array}{c}\text { Hypoplastic anemia } \\
\text { (HA) }(29.5)\end{array}$ & $\begin{array}{c}\text { Megaloblastic } \\
\text { anemia (MA) (23.6) }\end{array}$ \\
\hline 2. & $\begin{array}{l}\text { BN Gayathri } \\
\text { et al [6]. }\end{array}$ & India & 2005 & 104 & MA (74.04) & $\begin{array}{c}\text { Aplastic anemia } \\
(18.26)\end{array}$ \\
\hline 3. & $\begin{array}{c}\text { Kumar R } \\
\text { et al [7]. }\end{array}$ & India & 2001 & 166 & Aplastic anemia (29.5) & $\begin{array}{l}\text { Megaloblastic } \\
\text { anemia }(22.3)\end{array}$ \\
\hline 4. & $\begin{array}{l}\text { Naeem Khan } \\
\text { et al [8]. }\end{array}$ & Pakistan & 2001 & 30 & Aplastic anemia (20) & $\begin{array}{c}\text { Megaloblastic } \\
\text { anemia16.7) }\end{array}$ \\
\hline 5 . & $\begin{array}{l}\text { Khodke } \\
\text { et al [9]. }\end{array}$ & India & 2000 & 166 & $\begin{array}{c}\text { Hypoplastic anemia } \\
(29.5)\end{array}$ & $\begin{array}{c}\text { Megaloblastic } \\
\text { anemia(22.3) }\end{array}$ \\
\hline 6. & $\begin{array}{c}\text { Savage D G } \\
\text { et al [10]. }\end{array}$ & Zimbabwe & 1999 & 134 & Megaloblastic anemia & Aplastic anemia \\
\hline 7. & $\begin{array}{c}\text { Tilak V, } \\
\text { Jain R[11] }\end{array}$ & India & 1998 & 77 & $\begin{array}{c}\text { Megaloblastic anemia } \\
(68)\end{array}$ & Aplastic anemia (7.7) \\
\hline 8. & $\begin{array}{l}\text { Varma N, } \\
\text { Dash S[12] }\end{array}$ & India & 1992 & 202 & Aplastic anemia(40.6) & $\begin{array}{c}\text { Megaloblastic } \\
\text { anemia(23.2) }\end{array}$ \\
\hline 9. & $\begin{array}{l}\text { Hossain M } \\
\text { et al [13]. }\end{array}$ & Bangladesh & 1992 & 50 & Aplastic anemia & $\begin{array}{c}\text { Chronic malaria and } \\
\text { kala azar }\end{array}$ \\
\hline 10. & $\begin{array}{c}\text { Int.agranulocytosisstu } \\
\text { dy[14] }\end{array}$ & Europe & 1987 & 389 & Aplastic anemia(52.7) & MDS (10.5) \\
\hline 11. & Present study & India & 2012 & 134 & $\begin{array}{c}\text { Megaloblastic } \\
\text { anemia(37) }\end{array}$ & $\begin{array}{l}\text { Nutritional } \\
\text { anemia(31) }\end{array}$ \\
\hline
\end{tabular}




\section{Original Research Article}

aspiration and trephine biopsy [3]. Age group and cellularity of the marrow helps in narrowing the diagnosis (table1, 2). In the present study Megaloblastic Anemia was the commonest cause of pancytopenia (37\%) and the second commonest cause was Mixed Nutritional Anemia (31\%) (Table 3) which was similar to the study by Sudha Horakereppa showing megaloblastic anemia as the commonest cause (39.6\%) and the second commonest cause was Mixed Nutritional Anemia $(24.1 \%)[4]$

Other causes next to megaloblastic anemia were Hypersplenism (16\%), Aplastic anemia (6\%), malignant diseases Acute leukemia and Multiple myeloma (2.5\%), Myelodysplastic syndrome (MDS) (0.75\%), Cryptococcal infection $(0.75 \%)$. Six percent of bone marrow aspirates and biopsies were unsatisfactory.

The commonest cause of pancytopenia, reported from studies across the world has been aplastic anemia $[3,4,8,9,10]$ (table 5). This is in sharp contrast with the results of present study where the commonest cause of pancytopenia was megaloblastic anemia. This thus reflects the higher prevalence of mixed nutritional anemia in Indian population as shown by other Indian studies [6,11].

The ages range in study by Jha et aland Kumar et alwas 10-79 years and 14-73 years respectively, both with a malepreponderance [5,7]. In the present study age ranged from 15-70 years (table 1).

The peripheral examination, showed varying degrees of anemia with moderate degree of anisopoikilocytosis and macroovalocytosis, leukopenia along with hyper-segmented neutrophils and thrombocytopenia. These findings were similar to other studies by Khodke $\mathrm{K}$ et al and Tilak et al $[9,11]$.

In the present study, bone marrow was hypercellular in majority $(86 \%)$ of patients and normocellular in seven cases $(14 \%)$. Erythroid hyperplasia with megaloblastic maturation was seen in most of the patients.

In aplastic anemia bone marrow is hypocellular or acellular. Lymphocytes and plasma cells are prominent. In the present study, bone marrow was mostly hypocellular and the aspirate mainly composed of fat cells in all the patients. There were relative increase in lymphocytes and plasma cells. Bone marrow biopsy revealed replacement of marrow by adipocytes. Sixty percent had normocytic normochromic erythrocytes and $40 \%$ of the patients had macrocytic anemia.

Similar to study done by Daniel NM et alshowing the picture in $64 \%$ and $20 \%$ cases respectively [15]. In the study done by Tilak et al two out of six patients of aplastic anaemia had anisocytosis and three out of six patients had relative lymphocytosis [11].

Mixed nutritional anemia is a most common etiological factor causing pancytopenia. Megaloblastic anemia results as a nutritional deficiency of vitamin B12 or folate. Other causes include mixed deficiency anemia scausing microcytic and macrocytic anemias due to deficiency of iron, vitamin B12 and folate. In the studies done by Sharif M et al and Shazia Memon et al $11.2 \%$ and $8.69 \%$ cases were due to mixed deficiency anemias respectively [16,17].

Present study showed mixed deficiency in $31 \%$ cases, majority revealing dimorphic anemia. Bone marrow was hypercellular in 22 out of 41 cases. Erythroid hyperplasia with both megaloblastic and micronormoblastic maturation was observed in most of the patients. Leukopoiesis was normal. Megakaryopoiesis was either normal or increased.

Hypersplenism causes pancytopenia by sequestration of blood cells. Shazia Memon et al, Retief HP et al and Kumar et alreported hypersplenism in $4.34 \%, 7.7 \%$ and $11.4 \%$ cases respectively $[7,17]$. In the present study hypersplenism was the cause of pancytopenia in $16 \%$ of cases. In the present study majority $(68 \%)$ of patients with hypersplenism had hypercellular marrow while the rest (32\%) had normocellular marrow (table 3).

In the study done by Jha et al, acute leukemia alone constituted $90.6 \%$ of all the hematolgical malignancies. It accounted for $(19.5 \%)$ of total cases of pancytopenia [5]. In the present study malignant diseases accounted for $2.5 \%$ of pancytopenia cases of which two were cases of Acute leukemia and one case of Multiple myeloma (table 3). Bone marrow was hypercellular in cases of Acute Leukemia. It was normocellular in Multiple Myeloma case. Pancytopenia is less common as compared to Monocytopenia and bicytopenia in MDS. In a study by Kini J et al on MDS patients, bicytopenia was the commonest finding [18]. 


\section{Original Research Article}

Cryptococcal involvement of bone marrow is very rare. Ashwini B R et al reported a case of 50yr old HIV positive male whose bone marrow was hypercellular with normoblastic and megaloblastic erythropoiesis [19]. There was dense infiltration by cryptococci. Leukopoiesis and megakaryopoiesis were normal.

Pancytopenia is an indicator and not a diagnosis on its own. It requires vigorous work up of peripheral smear, counts and bone marrow studies. Bone marrow aspiration and trephine biopsy play a critical role in establishing the accurate and definitive diagnosis. This aids in appropriate management and correction of peripheral blood picture of pancytopenia.

\section{Conclusion}

Pancytopenia is an important clinic-hematological entity encountered in our day-to-day clinical practice. The spectrum of pancytopenia is broad. The possible underlying etiologies range from transient viral marrow suppression to life-threatening malignant neoplasms.

This study reveals that megaloblastic anemia is the commonest cause of pancytopenia in India. Bone marrow examination- aspiration and biopsy are important diagnostic tools inhematology to evaluate various causes of pancytopenia. Bone marrow examination is accurate, reproducible, economicaland gives minimal discomfort to the patient. A combination of diagnostic parameters namely peripheral smear finding, bone marrow examination finding along with clinical and radiological findings should be considered in order to accomplish the final diagnosis.

This study, along with explicating the differentials of pancytopenia, also stresses on bone marrow examination as the basic and a self-sufficient investigation in such cases, thereby reinforcing the existing data regarding the importance of bone marrow aspiration and biopsy. Also, it unfolds the various causes of pancytopenia especially in North Karnataka region of India.

Funding: Nil, Conflict of interest: None initiated Permission from IRB: Yes

\section{References}

1. Jiskani SA, Mahesar SM, Mahesar A. Etiological evaluation of pancytopenia in children and adult patients based on bone marrow biopsy. Pak. J Biotechnol. 2017; 14 (1); 97-9.

2. Pathak R, Jha A, Sayami G. Evaluation of bone marrow in patients with Pancytopenia. Nepal J Pathol; 2012; 2(4): 265-71.DOI: http://dx.doi.org/10.3126/jpn. v2i4.6875

3. Bangi SC, Reddy KD, Sreedhar VA Study of Bone Marrow Aspiration Smears and Trephine Biopsy in Pancytopenia Cases Annals of Applied Bio-Sciences, 2016; 3(3): 251-5.
4. Metikurke SH, Krishnappa R, Bhavika R.Correlation of Bone Marrow Aspirate, Biopsies and Touch Imprint Findings in Pancytopenia. J Hematol. 2013;2(1):8-13. doi: http://dx.doi.org/10.4021/jh76w.

5. Jha A, Sayami G, Adhikari RC, Panta AD, Jha R. Bone marrow examination in cases of pancytopenia. JNMA J Nepal Med Assoc. 2008 Jan-Mar;47(169): $12-7$.

6. Gayathri BN, Rao KS. Pancytopenia: a clinicohematological study. J Lab Physicians. 2011 Jan;3(1):15-20. doi: 10.4103/0974-2727.78555.

7. Kumar DB, Ragupathi AR. Clinicohematologic Analysis of Pancytopenia: Study in a tertiary care centre. Basic and Applied Pathology 2012; 5: 19-21 . https : // doi. org/ 10. 1111 /j. 1755-9294. 2011. 01121.x

8. Khan NU, Tariq M, Basri R. Etiology of pancytopenia. Professional J Med. 2010; 17 (2): 252-6.

9. Khodke K, Marwah S, Buxi G, Yadav RB, Chaturvedi NK. Bone Marrow Examination cases of Pancytopenia. JIACM 2001; 2: 55-9.

10. Savage DG, Allen RH, Gangaidzo IT, Levy LM, Gwanzura C, Moyo A, Mudenge B, Kiire C, Mukiibi J, Stabler SP, Lindenbaum J. Pancytopenia in Zimbabwe. Am J Med Sci. 1999 Jan;317(1):22-32.

11. Tilak V, Jain R. Pancytopenia--a clinicohematologic analysis of 77 cases. Indian J Pathol Microbiol. 1999 Oct;42(4):399-404.

12. Mishra B, Malhotra P, Ratho RK, Singh MP,Varma S, Varma N. Humanparvovirus B19 in patients with Aplastic anemia. Am J Hematol; 79: 166-7.DOI: 10. 1002/ ajh.20347.

13. Hossain MA, Akond AK, Chowdhary MK. Pancytopenia A study of 50 cases. Bangladesh J Pathol 1992;1: 9-12. 
14. Incidence of aplastic anemia: the relevance of diagnostic criteria. By the International Agranulocytosis and Aplastic Anemia Study. Blood. 1987 Dec; 70 (6): 1718-21.

15. Daniel NM, Byrd S. Aplastic anemia: Analysis of 50 cases. Ann Intern Med 1958; 49: 326-36.

16. Sharif M, Masood N, ul Haq MZ, Dodhy MA, Muhammad R. Etiological spectrum of pancytopenia/ bicytopenia in children 2 months to 12 years of age. Journal of Rawalpindi Medical College (JRMC). 2014; 18 (1):61-4.
Original Research Article

17. Memon, S, Shaikh, S, Nizamani MA. Etiological spectrum of pancytopenia based on bone marrow examination in children. J Coll Physicians Surg Pak. 2008;18:163-7.

18. KiniJR, Suresh PK, SinhaR, Sahu KK, KumarS, Prasad K. Value of bone marrow examination in hodgkin lymphoma: report of three cases with review of literature. J Can Res Ther 2012;8:457-9.doi: 10.4103/ 0973-1482.103535.

19.B R A, Raghupathi A, A S. Cryptococcososis of bone marrow: a case report with review of literature. $\mathrm{J}$ Clin Diagn Res. 2014 Jan; 8 (1):158-9. doi: 10.7860 / JCDR/2014/6478.3807. Epub 2014 Jan 12.

\section{How to cite this article?}

Chandan R.H, Giriyan S.S. Role of bone marrow aspiration and biopsy in elaborating the diagnosis of pancytopenia. Trop J Path Micro 2018;4(2):144-149. doi: 10.17511/jopm.2018.i2.04 